\title{
PENERAPAN SISTEM EVALUASI KETERAMPILAN MENARI BERBASIS IT DI SANGGAR TARI
}

\author{
Dinny Devi Triana, Indah Juniansih \\ Program Studi Pendidikan Tari \\ Program Studi Pendidikan Anak Usia Dini \\ e-mail: dinnydevi@unj.ac.id, indahpaud80@gmail.com
}

\begin{abstract}
Abstrak
Kegiatan pengabdian masyarakat untuk membantu sanggar yang memiliki lebih dari 100 orang peserta didik dalam melaksanakan evaluasi keterampilan menari, sebelum diadakan ujian kenaikan tingkat. Kegiatan pengabdian masyarakat ini berupa penerapan sistem evaluasi dengan menggunakan web e-assessment yang dapat membantu instruktur dalam memantau perkembangan keterampilan menari peserta didiknya selama proses pembelajaran. Kegiatan ini melibatkan dua mitra sangar tari dengan mempertimbangkan jumlah peserta didik, prestasi yang telah diperoleh sanggar tari, kompetensi instruktur, dan kurikulum yang dimiliki sanggar. Metode penerapan pengabdian dilaksanakan dengan 6 kali pertemuan dengan materi 1) pengenalan tujuan dan manfaat menggunakan sistem evaluasi yang berbasis IT, 2) praktik penggunaan web e-assessment yang dimulai dari membuka kelas atau log in kelas, membuka kursus, membuat indikator kemampuan, mengklasifikasikan materi ke dalam tiap tingkatan, cara meng-up load materi tari yang diujikan, 3) memberikan umpan balik bagi instruktur. Hasil dari kegatan ini diharapkan dapat meningkatkan kualitas pembelajaran tari di sanggar, baik instruktur maupun pimpinan sanggar dalam memonitoring keterampilan menari siswa di setiap ragam geraknya dari waktu ke waktu secara berkelanjutan, dengan mudah dan terdokumentasi.
\end{abstract}

Kata kunci: sistem evaluasi, keterampilan menari, sanggar tari, web e-assessment, teknologi informasi, instruktur tari

\section{PENDAHULUAN}

Evaluasi merupakan proses yang menentukan kondisi, di mana suatu tujuan telah dapat dicapai (Sukardi, 2009). Sesuai dengan pendapat tersebut maka evaluasi hasil belajar dapat diartikan sebagai suatu tindakan atau suatu proses untuk menentukan nilai keberhasilan belajar setelah mengalami proses belajar selama satu periode tertentu. Evaluasi dilakukan sebagai bagian dari integral program pendidikan, baik di dalam kelas maupun di luar kelas (Crooks, 1988). Sesungguhnya evaluasi pada pembelajaran dilaksanakan tidak hanya pada akhir pembelajaran, tetapi juga selama pembelajaran berlangsung.

Evaluasi keterampilan menari pada sanggar tari sebagai lembaga pendidikan non formal, dilakukan melalui uji kompetensi saat ujian kenaikan tingkat, dan lebih menekankan pada produk atau hasil. Sistem evaluasi yang dilakukan sebelum ujian kenaikan tingkat dengan materi ujian yang berbeda-beda, mulai dari tingkat dasar, 
trampil, dan mahir. Demikian pula dengan sanggar tari yang berkembang di daerah Jakarta, Bogor, Depok, Tangerang, Bekasi, masing-masing memiliki keunggulan baik dari sisi materi, frekuensi pementasan, prestasi yang diperoleh, maupun pengembangan keterampilan untuk menjadi profesional. Namun demikian pengelolaan sanggar tari yang ada, masih menggunakan sistem konvensional, terutama dalam penyusunan materi pada tingkat atau jenjang yang dipakai, serta pelaksanaan ujian kenaikan tingkat yang memerlukan waktu dan ketidakjelasan indikatornya karena tidak merujuk pada capaian kompetensi keterampilan menari yang harus dimiliki peserta didik.

Pada sanggar tari Larasati di Depok dan Sanggar tari Gandes Pamantes di Bogor memiliki peserta didik di atas 100 orang, prestasinya cukup baik, dan seringkali mengadakan pementasan untuk kepentingan pemerintah daerah setempat. Ke dua sanggar tersebut mengembangkan kesenian tradisional, peserta didiknya dari tingkat sekolah dasar sampai sekolah lanjutan, memiliki prestasi dalam dan luar negeri, dipimpin oleh alumni seni tari Universitas Negeri Jakarta.

Evaluasi ini diterapkan dengan mempertimbngkan kebutuhan sanggar, khususnya pada capaian kompetensi keterampilan menari. Kompetensi merupakan suatu kecakapan yang ditunjukan dengan perilaku untuk berbagai tujuan (Boyatzis, 2007), kompetencimengacu pada pengetahuan, sikap, dan keterampilan yang secara konseptual atau empiris ditunjukkan dengan identifikasi perilaku yang dilakukan (Ulrich, Brockbank, 1995). Kompetensi juga menekankan pada kemampuan untuk melakukan atau mendemonstrasikan suatu keterampilan secara efektif sesuai dengan tuntutan dan kebutuhan lapagan (Wolters, 2010).

Pengukuran terhadap kompetensi keterampilan menari telah dilakukan yang disebut dengan Performance Competence Evaluation Measure (PCEM) yang terdiri dari aspek kualitatif pada pertunjukan tari, baik pada gerakan maupun kegiatan menari (Krasnow, and Chatfield, 2009). Khusus pada capaian kompetensi, umumnya sanggarsanggar tari belum memiliki standar kompetensi yang harus dipenuhi untuk masingmasing tingkat kemampuan, sehingga indikator yang ditetapkan sebagai syarat kenaikan tingkat lebih kepada kemampuan menari dari tari yang dibawakan peserta didik sebagai hasil dari pembelajaran. Untuk itu kemampuan menari pada saat ujian kenaikan tingkat bukan ditentukan pada usia peserta didik, tetapi keterampilan menari yang dikuasai peserta didik.

Kompetensi perlu didefinisikan dan disesuaikan dengan visi-misi sanggar, demikian pula sistem pembelajaran yang mengacu pada kurikulum yang ditetapkan, mengingat materi tari untuk setiap tingkatan tidak dipahami berdasarkan indikator capaian kompetensi, tetapi lebih pada keterampilan dan tingkat kesulitan gerak saja. Indikator capaian kompetensi dapat disusun melalui pengamatan sistem evaluasi selama proses yang terdokumentasi dengan baik.

Proses pembelajaran tari menekankan pada kegiatan praktik, untuk itu diperlukan IT yang dapat membantu sistem evaluasi keterampilan menari sebagai bagian integral dari proses pembelajaran, di mana IT dikembangkan agar dapat bertahan hidup di era digital (Morris and Helena, 2007). Teknologi sebagai sistem perangkat lunak yang dibuat untuk simulasi, dan pembelajaran dalam menghadapi bidang-bidang signifikan diadopsi serta diterapkan di berbagai institusi pendidikan (Weston, 2004). Pembelajaran yang konvensional telah mengalami pergeseran kebutuhan dan telah mentrasnformasi sistem pembelajaran yang dibantu tekhnologi, sehingga pembelajaran menjadi efektif, efesien dan bermakna (Garrison, Kanuka, 2004). 
Perlu diperhatikan bahwa penerapan teknologi dalam sistem informasi perusahaan (dalam hal ini sanggar tari) hendaknya mempertimbangkan pemakai sistem, sehingga teknologi yang diterapkan dapat bermanfaat sesuai dengan tugas dan kemampuan pemakai (Jumaili, Jurnal: SNA VIII Solo, 15 - 16 September 2005). Untuk itu diperlukan pelatihan dalam penggunaan dan pemanfaatan IT sebagai bagian dari sistem evaluasi dalam pembelajaran, yang akan membantu peserta didik dalam menyelesaikan tugas-tugas yang diberikan. Sejalan dengan hal tersebut Goodhue (1995) mendefinisikan teknologi sebagai alat yang digunakan oleh individu untuk membantu menyelesaikan tugas-tugas mereka, khususnya dalam mengukur kompetensi keterampilan menari peserta didik.

Hal ini yang dilakukan di sanggar tari Larasati dan Gandes Pamantes pada sistem evaluasi formatif, di mana teknologi yang diterapkan dapat bermanfaat sesuai dengan tugas dan kemampuan pemakai (Jumaili, 2005). Dengan demikian teknologi sebagai alat yang digunakan oleh individu untuk membantu menyelesaikan tugas-tugas mereka (Goodhue, 1995). Tugas-tugas tersebut dapat terdokumentasi dalam bentuk portofolio yang disimpan dalam konten yang terdapat dalam IT tersebut, sebagaimana pendapat (Stansberry and Kymes, 2007) yang menjelaskan bahwa portofolio dapat membantu refleksi secara kritis. Refleksi merupakan umpan balik yang positif sebagai bukti yang terkait dengan pencapaian pembelajaran (Hattie and Timperley, 2007)

Sistem evaluasi keterampilan menari yang dilakukan dalam pembelajaran dengan berbasis IT ini diperlukan literasi informasi, karena dibutuhkan pemahaman tentang budaya dan konteks digital dalam lingkungannya agar dapat beroperasi secara efektif (Morris and Helena, 2007). Namun demikian, banyak masalah dalam implementasinya yang disebabkan sumber daya dan perspektif dalam penggunaan IT pada pembelajran di era digital, di mana sumber daya khususnya lingkungan belajar merupakan tantangan yang harus dihadapi (Janette, Michael, Hannafin, 2001).

Demikian pula halnya dengan tekhnologi yang digunakan pada sistem evaluasi keterampilan menari di sanggar tari Larasati Depok dan Gandes Pamantes Bogor. Hal ini dapat dilakukan dengan baik, jika telah dirumuskan 1) capaian kompetensi untuk masingmasing tingkat kemampuan keterampilan menari di sanggar tari Larasati dan Gandes Pamantes yang sesuai dengan visi dan misi sanggar tari dalam bentuk pelatihan dan pendampingan, 2) merumuskan materi tari yang sesuai dengan capaian kompetensi sesuai dengan dan visi-misi sanggar, serta 3) melaksanakan evaluasi yang sistematis, transparan, memberikan umpan balik sebagai bahan refleksi bagi peseserta didik, dan terdokumentasi. Sistem evaluasi keterampilan menari berbasis IT yang dilakukan dalam bentuk web site ini dapat digunakan peserta didik, instruktur, maupun pimpinan sanggar tari sebagai pendiagnostik sebelum pelaksanaan ujian kenaikan tingkat yang selama ini digunakan di kedua sanggar tersebut.

\section{METODOLOGI}

Penerapan sistem evaluasi keterampilan menari menitikberatkan pada diagnosis kompetensi siswa untuk mempersiapkan ujian kenaikan tingkat dengan menggunakan IT berupa web $e$-assessment. Penerapan sistem ini terbagi menjadi 2 kelompok yang harus diikuti masing-masing sanggar sebagai mitra dalam kegiatan pengabdian masyarakat. Sanggar tari Larasati di Depok dan sanggar tari Gandes Pamantes di Bogor. Pertimbangan menjadi 2 kelompok karena karakterstik sanggar yang berbeda. Pada sanggar tari Larasati materi terkait dengan tari-tari Betawi, sedangkan sanggar tari 
Jurnal SEMAR Vol. 7 No. 2, 2018 hal. 1 - 14

ISSN: 2302-3937 | Copyright ( LPPM Universitas Sebelas Maret Homepage: https://jurnal.uns.ac.id/jurnal-semar

Gandes Pamantes materi tari Jaipongan. Begitu pula teknis pelaksanaan kegiatan sanggar memiliki kebijakan yang berbeda-beda.

Metode pelaksanaan kegiatan dilakukan dengan beberapa tahapan pendampingan dan pelatihan, yaitu:

\begin{tabular}{|c|c|c|c|}
\hline No & Tahap & Kegiatan & Output \\
\hline 1 & Obsevasi & $\begin{array}{l}\text { Melakukan pengamatan } \\
\text { terhadap proses } \\
\text { pembelajaran }\end{array}$ & $\begin{array}{l}\text { Teridentifikasi } \\
\text { kebutuhan peserta didik }\end{array}$ \\
\hline 2 & $\begin{array}{l}\text { Kaji } \\
\text { dokumen }\end{array}$ & $\begin{array}{l}\text { Menganalisis dokumen profil, } \\
\text { visi- misi, kurikulum, ujian } \\
\text { kenaikan tingkat sanggar tari, } \\
\text { dan kegiatan lainnya }\end{array}$ & $\begin{array}{lr}\text { Teridentifikasi } & \\
\text { kekurangan dokumen } \\
\text { yang harus dimiliki } \\
\text { sanggar }\end{array}$ \\
\hline 3 & $\begin{array}{l}\text { Pendam- } \\
\text { pingan }\end{array}$ & 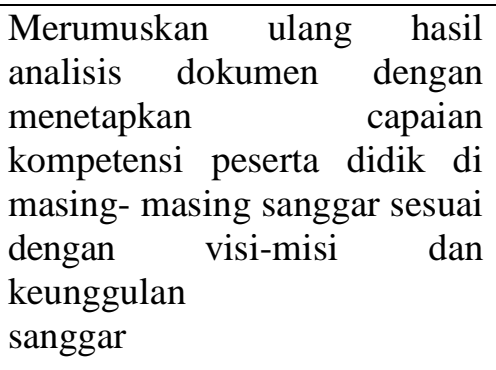 & $\begin{array}{l}\text { Menghasilkan rumusan } \\
\text { profil sanggar yang } \\
\text { dimulai dari visi-misi, } \\
\text { dan capaian kompetensi, } \\
\text { serta kurikulum sanggar }\end{array}$ \\
\hline \multirow[t]{2}{*}{4} & \multirow[t]{2}{*}{$\begin{array}{l}\text { Pendam- } \\
\text { pingan } \\
\text { dan } \\
\text { pelatihan }\end{array}$} & $\begin{array}{l}\text { Menyiapkan sistem evaluasi } \\
\text { keterampilan menari berbasis } \\
\text { IT sebagai dasar dalam } \\
\text { menentukan kelayakan siswa } \\
\text { mengikuti ujian kenaikan } \\
\text { tingkat. }\end{array}$ & $\begin{array}{l}\text { Menyediakan system IT } \\
\text { berupa web e-assessment } \\
\text { untuk melaksanakan } \\
\text { evaluasi keterampilan } \\
\text { menari }\end{array}$ \\
\hline & & $\begin{array}{l}\text { Mengujicobak an sistem } \\
\text { evaluasi keterampilan }\end{array}$ & $\begin{array}{l}\text { Melaksanakan dan } \\
\text { menggunakan sistem }\end{array}$ \\
\hline
\end{tabular}




\begin{tabular}{|c|l|l|l|}
\hline No & Tahap & \multicolumn{1}{|c|}{ Kegiatan } & \multicolumn{1}{c|}{ Output } \\
\hline & & $\begin{array}{l}\text { menari berbasis IT sebagai } \\
\text { dasar dalam menentukan } \\
\text { kelayakan siswa mengikuti } \\
\text { ujian kenaikan tingkat. }\end{array}$ & $\begin{array}{l}\text { evaluasi keterampilan } \\
\text { menari yang telah } \\
\text { dirancang dan } \\
\text { disediakan pada tahap } \\
\text { sebelumnya }\end{array}$ \\
\hline 5 & $\begin{array}{l}\text { Menge- } \\
\text { valuasi }\end{array}$ & $\begin{array}{l}\text { Mendokumen tasikan hasil } \\
\text { evaluasi keterampilan menari, } \\
\text { dan menganalisis kelemahan } \\
\text { atau kesulitan- kesulitan yang } \\
\text { dihadapi peserta didik atau } \\
\text { instruktur }\end{array}$ & $\begin{array}{l}\text { Memperbaiki jika } \\
\text { sistem evaluasi } \\
\text { keterampilan menari } \\
\text { berbasis IT masih sulit } \\
\text { untuk digunakan }\end{array}$ \\
\hline 6 & $\begin{array}{l}\text { Pelapor- } \\
\text { an }\end{array}$ & $\begin{array}{l}\text { Membuat panduan sistem } \\
\text { evaluasi keterampilan menari } \\
\text { yang dapat digunakan dengan } \\
\text { mudah dan praktis }\end{array}$ & $\begin{array}{l}\text { Menghasilkan sistem } \\
\text { evaluasi keterampilan } \\
\text { menari yang dapat } \\
\text { digunakan dengan } \\
\text { mudah dan praktis }\end{array}$ \\
\hline
\end{tabular}

Pada pelaksanaan ini diperlukan sarana yang dapat mendukung, seperti tersedianya wifi yang cukup baik, peserta didik dan instruktur yang cakap dalam menggunakan IT, serta ketelitian pada saat melaksanakan evaluasi pembelajaran tari.

\section{HASIL, PEMBAHASAN, DAN DAMPAK}

\section{Deskripsi Sanggar Tari}

a Sanggar Tari Larasati di Depok

Materi tari yang diujikan di Sanggar tari Larasati terdiri dari 3-4 materi tari yang berbeda-beda di setiap jenjangnya. Ujian kenaikan tingkat dilaksanakan 1 kali dalam 1 tahun, tetapi siswa wajib memilih hanya 1 materi tari saja. Persyaratan mengikuti ujian adalah jumlah kehadiran 90\%, jadi minimal 10\% siswa diperbolekan ijin yaitu 5 kali tidak hadir dari total kehadiran 40 pertemuan dalam satu tahun. Jika tidak hadir lebih dari 5 kali pertemuan, maka akan ada kelas tambahan berbayar di luar jam kelas pertemuan.

Setiap tahun sangar tari Larasati mengadakan rapat kerja guna menentukan target peserta didik sanggar. Tingkat peserta didik sanggar Larasati, dibagi menjadi: Dasar 1 $\mathrm{s} / \mathrm{d} 3$, dan tingkatan lanjutan $1 \mathrm{~s} / \mathrm{d} 9$ dengan standar kriteria ketuntasan minimal (KKM) dengan nilai 75 .

Sanggar tari Larasati terdapat di beberapa lokasi yaitu:

a) Kecamatan Sukmajaya terdapat 4 kelas. Waktu latihan hari minggu jam 08.00-14.00, waktu latihan masingmasing kelas yaitu 1,5 jam

b) Flamboyan terdapat 3 kelas. Waktu latihan pada hari minggu jam 08.00-13.00, hari sabtu jam 
16.00 - 18.00. pada hari jumat 16.00 - 18.00 .

c) Departemen Penerangan terdapat 2 kelas. Waktu latihan pada hari sabtu jam $16.00-18.00$

d) Mall Depok Town Square (DETOS) terdapat 1 kelas. Waktu latihan hari sabtu jam $16.00-18.00$.

e) Mampang Depok terdapat 1 kelas. Waktu latihan pada hari sabtu jam 15.30 16.30 .

f) Perumahan Mampang terdapat 1 kelas (franchase).

Kegiatan ujian di sanggar tari Larasati yang memiliki siswa kurang lebih 100, menghadapi beberapa kesulitan dalam pengelolaan ujian. Evaluasi keterampilan menari saat pembelajaran sangat membantu instruktur dalam menentukan siswa mana yang layak untuk mengikuti ujian, dan siswa mana yang masih harus memantapkan keterampilan menarinya agar syarat ujian memenuhi standar. Kegiatan ujian tengah semester dilakukan sebelum ujian kenaikan tingjat dengan menghadirkan 3 orang penguji. Pada ujian kenaikan tingkat terdapat 2 kewajiban yaitu pergelaran/lomba (di bulan November), ujian tengah semester, dan ujian kenaikan tingkat (di bulan April). Sanggar tari Larasati telah memiliki ijin usaha sejak tahun 2009.

\section{b. Sanggar Gandes Pamantes di Bogor}

Sanggar tari Gandes Pamantes mengembangkan materi tari Jaipongan. Tingkatan kemampuan pada Sanggar tari Gandes Pamantes terdiri dari: tingkat dasar (Taman Kanak-kanak), tingkat pemula I, II, III, tingkat Terampil I, II, III,IV,V,VI,VII, tingkat mahir, kelas koreografer/pencipta tari, kelas makeup, kelas tari nusantara.

Proses pelatihan tari dilakukan satu minggu sekali, pra evaluasi/midsemester 3 bulan sekali, Ujian kenaikan tingkat dilaksanakan setiap 1 semester (6 bulan) sekali pada akhir pelatihan. Teknis pelaksanaan ujian 1) Setiap peserta Tampil 2-3 orang, dinilai oleh 2 orang penilai, 3) siswa mendapatkan piala \& sertifikat Dinas Pariwisata dan Kebudayaan

\section{Materi Penerapan Sistem Evalausi Berbasis IT}

Evaluasi keterampilan menari yang berbasis IT pada sanggar tari Larasati Depok dan Gandes Pamantes Bogor dimulai dengan pengenalan, tujuan, dan manfaat IT pada sistem evaluasi yang dituangkan ke dalam bentuk web. Tujuan dari evaluasi dengan menggunakan web $e$ - assessment adalah: 1) membantu sanggar (instruktur) dalam mendiagnostik keterampilan menari siswa, 2) menggunakan web sebagai media yang memberikan kemudahan dalam mendiagnostik keterampilan menari siswa, 3) memberikan kemudahan bagi pimpinan sanggar sebagai manager untuk memantau kinerja instruktur dan kemajuan siswa, 4) memberikan kemudahan bagi instruktur dalam memantau perkembangan keterampilan menari siswa.

Adapun materi penerapan sistem evaluasi keterampilan menari berbasis IT di sangar tari berikut ini telah dipresentasikan dalam Internasional Conference Arts and Design Education (Triana, Juniasih, 2018), dengan langkah- langkah sebagai berikut: 
Jurnal SEMAR Vol. 7 No. 2, 2018 hal. 1 - 14

ISSN: 2302-3937 | Copyright ( LPPM Universitas Sebelas Maret Homepage: https://jurnal.uns.ac.id/jurnal-semar

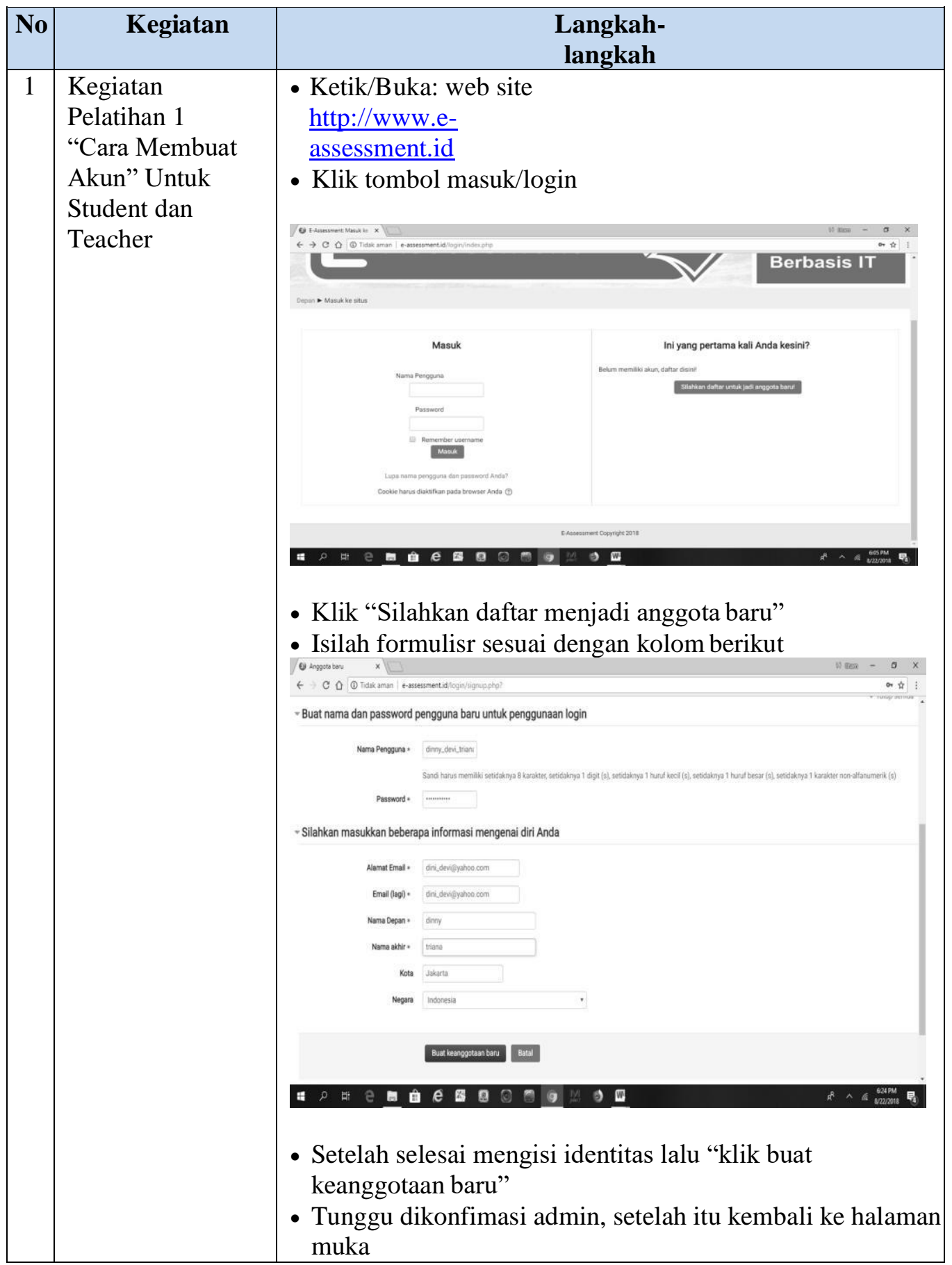




\begin{tabular}{|c|c|c|}
\hline 2 & $\begin{array}{l}\text { Mengonfir-masi } \\
\text { Student Dan } \\
\text { Teacher Oleh } \\
\text { Admin }\end{array}$ & $\begin{array}{l}\text { - Login, masukan user dan pass } \\
\text { - Klik site home } \\
\text { - Klik users } \\
\text { - Klik permission } \\
\text { - Klik assign system roles } \\
\text { - Klik manager untuk menjadi pemiliki sanggar } \\
\text { - Klik curde creator } \\
\text { - Ketik nama pengguna di kolom search atau kilk salah satu } \\
\text { nama } \\
\text { - Klik add }\end{array}$ \\
\hline 3 & Membuat Materi & $\begin{array}{l}\text { - Klik site home } \\
\text { - Klik course } \\
\text { - Klik add new curse } \\
\text { - Isi formulir sesuai kegiatan data kursus } \\
\text { - Klik and save display }\end{array}$ \\
\hline 4 & Membuat Topic & $\begin{array}{l}\text { - Klik site home } \\
\text { - Klik couse } \\
\text { - Klik kursus yang telah dibuat } \\
\text { - Klik turn editing on } \\
\text { - Klik edit pada slah satu topic } \\
\text { - Isi topic sesuai materi sanggar } \\
\text { - Klik save changes }\end{array}$ \\
\hline 5 & $\begin{array}{l}\text { Mengelom- } \\
\text { pokkan Kelas }\end{array}$ & $\begin{array}{l}\text { - Klik dashboard } \\
\text { - Klik site administration } \\
\text { - Klik user } \\
\text { - Klik account } \\
\text { - Klik cohorts } \\
\text { - Klik add new cohorts } \\
\text { - Isi form dengan data kelas } \\
\text { - Klik save changes }\end{array}$ \\
\hline 6 & $\begin{array}{l}\text { Cara } \\
\text { Menginput } \\
\text { Student Ke } \\
\text { Dalam Kelas }\end{array}$ & $\begin{array}{l}\text { - Klik dashboard } \\
\text { - Klik site administration } \\
\text { - Klik users } \\
\text { - Klik acoount } \\
\text { - Cari kelas yang telah dibuat, kemudain klik icon gambar } \\
\text { kepala } \\
\text { - Ketik nama pada kolom search yang akan dimasukan ke } \\
\text { dalam kelas terebut } \\
\text { - Klik add }\end{array}$ \\
\hline
\end{tabular}


Jurnal SEMAR Vol. 7 No. 2, 2018 hal. 1 - 14

ISSN: 2302-3937 | Copyright @ LPPM Universitas Sebelas Maret Homepage: https://jurnal.uns.ac.id/jurnal-semar

\begin{tabular}{|c|c|c|}
\hline 7 & $\begin{array}{l}\text { Cara } \\
\text { Memasukan } \\
\text { Kelas Ke } \\
\text { Dalam Kursus }\end{array}$ & $\begin{array}{l}\text { - Klik dashboard } \\
\text { - Klik course } \\
\text { - Pilih salah satu kursus yang akan ditambah ke student } \\
\text { - Klik administration } \\
\text { - Klik course completion } \\
\text { - Klik user } \\
\text { - Klik enrolled users } \\
\text { - Klik enroll users } \\
\text { - Pada menu cohotrs di kolom search pilih kelas yang } \\
\text { telah dibuat sebelumnya } \\
\text { - Klik enroll selected users and cohorts }\end{array}$ \\
\hline 8 & $\begin{array}{l}\text { Membuat } \\
\text { Company } \\
\text { Profile Sanggar }\end{array}$ & $\begin{array}{l}\text { - Klik dashboard } \\
\text { - Klik course } \\
\text { - Pilih salah satu sanggar } \\
\text { - Pada bagian administration di bawah klik edit category } \\
\text { - Isi form sesuai data sanggar } \\
\text { - Klik save change }\end{array}$ \\
\hline 9 & $\begin{array}{l}\text { Membuat } \\
\text { Kurikulum } \\
\text { Sanggar/Mengkasif } \\
\text { ika }\end{array}$ & $\begin{array}{l}\text { - Klik dashboard } \\
\text { - Klik course }\end{array}$ \\
\hline & $\begin{array}{l}\text { si Kursus } \\
\text { Berdasarkan } \\
\text { Tingkatan Dalam } \\
\text { Pelatihan Di } \\
\text { Sanggar }\end{array}$ & $\begin{array}{l}\text { - Pilih salah satu sanggar } \\
\text { - Klik create new category } \\
\text { - Isi dengan nama tingkatan pelatihan sanggar } \\
\text { - Klik create category } \\
\text { - Ceklist kursus yang telah dibuat } \\
\text { - Pada teks move selected couse di kolom choose } \\
\text { pilih category tingkatan sanggar yang telah dibuat } \\
\text { sebelumnya } \\
\text { - Klik move }\end{array}$ \\
\hline 10 & Up-load Video & $\begin{array}{l}\text { - Klik Dashboard } \\
\text { - Klik Course } \\
\text { - Klik Kursus Yang Telah Dibuat } \\
\text { - Klik Turn Editing On } \\
\text { - Klik Edit Topik } \\
\text { - Pada Kolom Summary Klik Icon Gambar Kamera Kecil } \\
\text { - Klik Video } \\
\text { - Brows Respository } \\
\text { - Klik Upload } \\
\text { - Klik pilih File } \\
\text { - Pilih file dalam Komputer } \\
\text { - Klik Open } \\
\text { - Klik Upload Display }\end{array}$ \\
\hline
\end{tabular}


Jurnal SEMAR Vol. 7 No. 2, 2018 hal. 1 - 14

ISSN: 2302-3937 | Copyright ( LPPM Universitas Sebelas Maret Homepage: https://jurnal.uns.ac.id/jurnal-semar

\begin{tabular}{|l|l|l|}
\hline 11 & Membuat & - Klik Dashboard \\
& Tindak Lanjut & - Klik Course \\
& & - Klik Course/tugas Yang Telah Dibuat \\
& & - Klik Grade \\
& & - Klik Salah Satu Bentuk Tugas Misal Essay \\
& & - Klik Salah satu nilai \\
& & - Klik Make Comment or Override Mark \\
& & \\
\hline
\end{tabular}

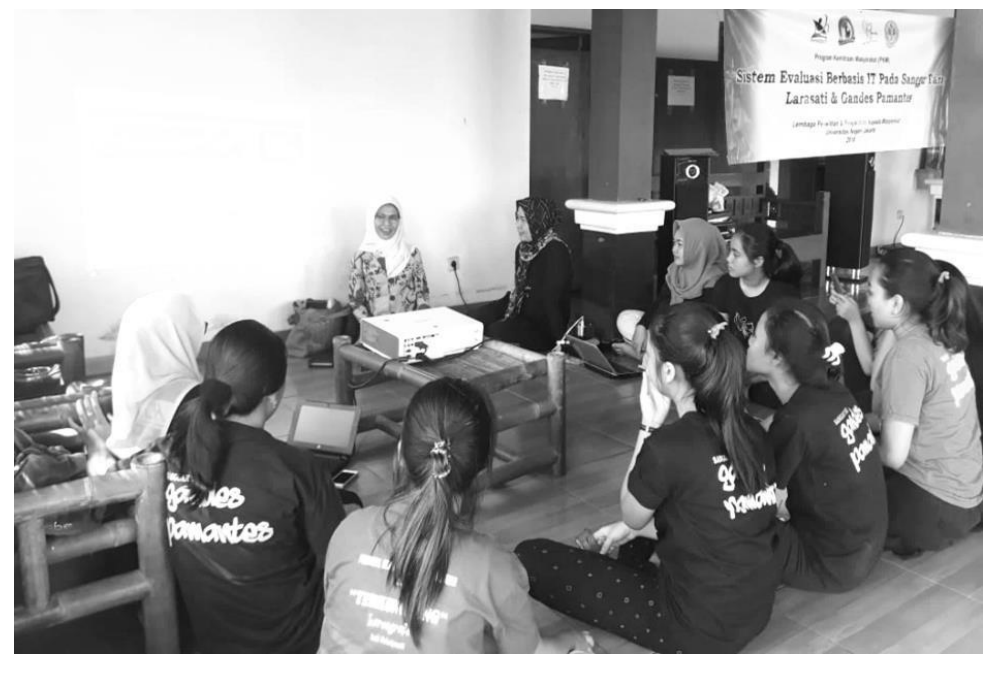

Sumber: Dokumen pribadi

Foto 1. Pelaksanaan kegiatan di sanggar tari Gandes Pamantes Bogor

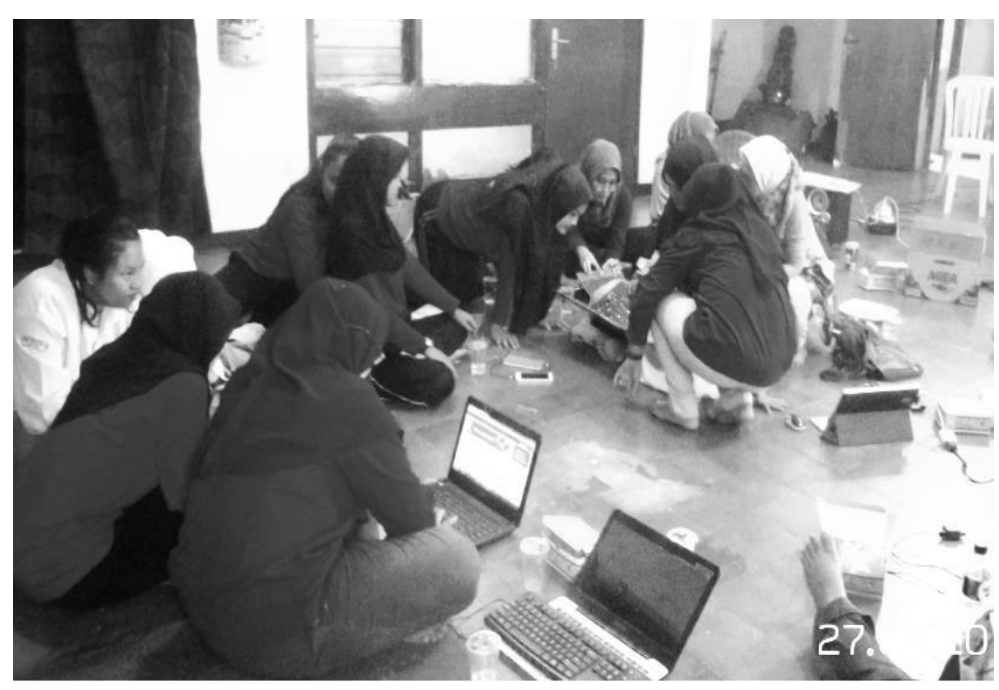

Sumber: Dokumen pribadi

Foto 2. Pelaksanaan kegiatan di sanggar tari Larasati Depok 
Jurnal SEMAR Vol. 7 No. 2, 2018 hal. 1 - 14

ISSN: 2302-3937 | Copyright @ LPPM Universitas Sebelas Maret Homepage: https://jurnal.uns.ac.id/jurnal-semar

Hal yang paling penting dalam sistem evaluasi keterampilan menari yang berbasis IT, adalah ketika siswa sanggar meng-up load video dari topik (ragam gerak) sesuai dengan tugas yang diberikan instruktur. Video-video dari ragam gerak yang di up-load siswa merupakan protofolio hasil pembelajaran sebagai portofolio elektronik yang dapat membantu mengetahui perkembangan belajar, sehingga dapat merefleksi secara kritis dan memberi keyakinan guru terhadap kemampuan siswa secara personal.

Berdasarkan portofolio tersebut instruktur memberikan umpan balik, baik berupa komentar maupun grade atau nilai, dan siswa dapat mengetahui bagian mana saja yang masih harus diiperbaiki. Umpan balik dapat memberikan informasi korektif dan dapat memberikan strategi alternatif dalam memberikan tanggapan terhadap jawaban siswa.

Berikut hasil pelatihan yang dapat dilihat pada web site: www.e- assessment.id

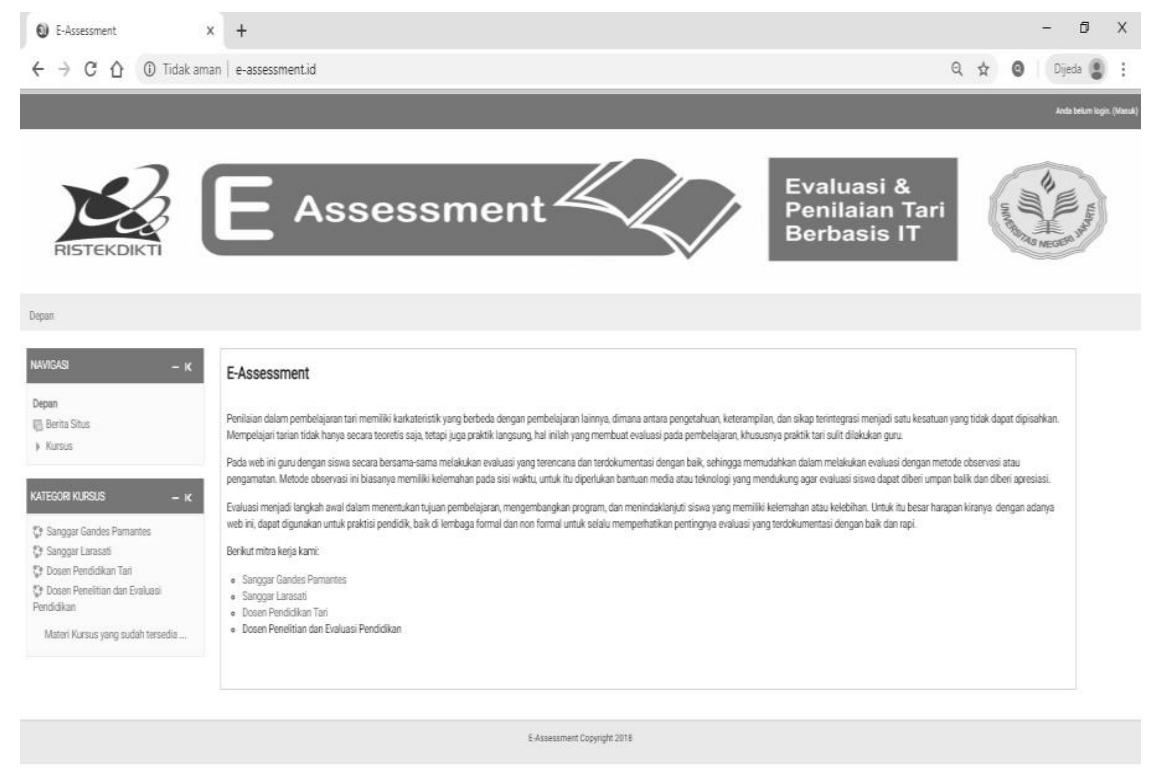

- $\rho$ 正

Gambar 1. Tampilan web e-assessment 
Jurnal SEMAR Vol. 7 No. 2, 2018 hal. 1 - 14

ISSN: 2302-3937 | Copyright @ LPPM Universitas Sebelas Maret Homepage: https://jurnal.uns.ac.id/jurnal-semar

a. Sanggar Tari Larasati

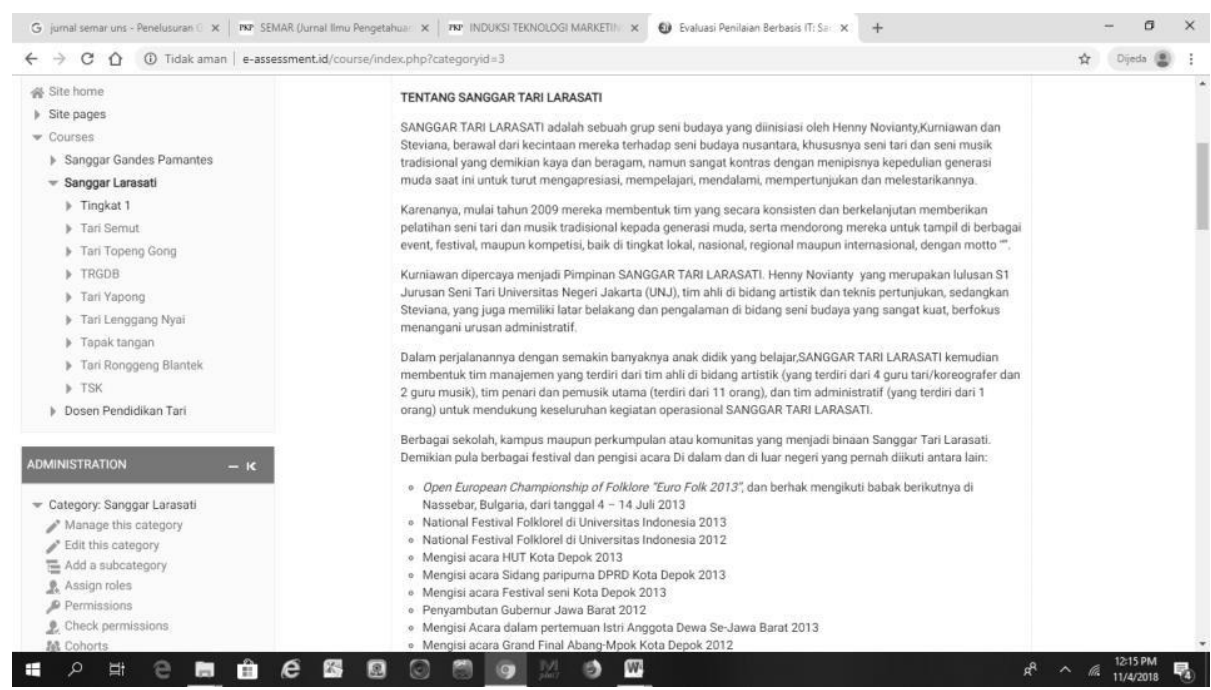

Gambar 2. Tampilan web e-assessment Sanggar Tari Larasati

b. Sanggar Tari Gandes Pamantes

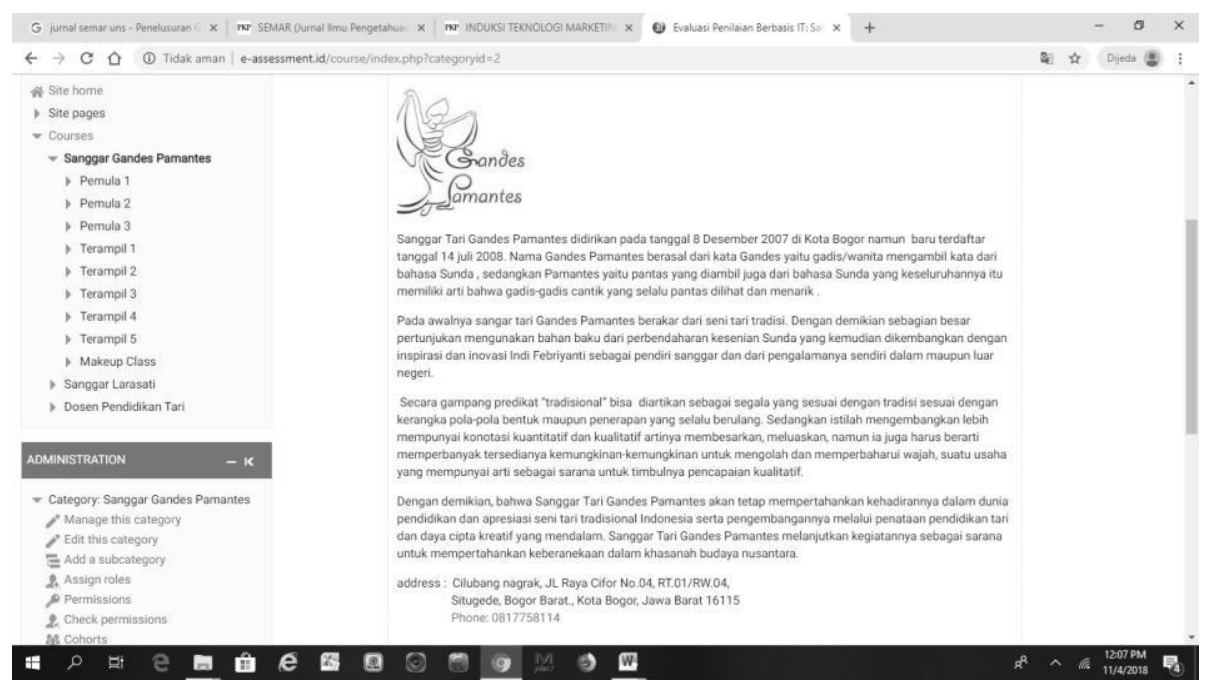

Gambar 3. Tampilan web e-assessment Sanggar Tari Gandes Pamantes

Selanjutnya pengguna web dapat menggumanakan sesuai dengan kebutuhan, baik sebagai admin, pimpinan sanggar, instruktur, maupun peserta didik. Masing-masing pengguna dapat mengikuti 11 langkah yang telah dijelaskan dalam menerapkan system evaluasi keterampilan menari dengan menggunakan web e-assessment. 
Jurnal SEMAR Vol. 7 No. 2, 2018 hal. 1 - 14

ISSN: 2302-3937 | Copyright @ LPPM Universitas Sebelas Maret Homepage: https://jurnal.uns.ac.id/jurnal-semar

\section{PENUTUP}

Penerapan sistem evaluasi keterampilan menari di sanggar tari dengan menggunakan IT berupa web $e$-assessment menghasilkan:

1. Profile Sanggar yang sudah diinput pada web e-assessment dapat diketahui siswa, orang tua, maupun masyaraat luas pengguna web, sehingga dapat diketahui kualitas dari sanggar tersebut.

2. Kurikulum sanggar tari dapat dinilai publik dan dipilih, sesuai dengan kebutuhan pengguna.

3. Capaian kompetensi untuk masing- masing tingkat kemampuan keterampilan menari di sanggar tari

4. dapat diketahui siswa dan orang tua sebagai indikator tercapainya pembelajaran.

5. Sistem evaluasi yang sistematis, valid, objektif, dan transparan bagi peseserta didik, serta terdokumentasi dengan baik dapat dilakukan melalui sistem yang berbasis IT berupa web $e$-assessment.

6. Penggunaan IT pada pembelajaran di era digital, khususnya sumber daya dan lingkungan belajar merupakan tantangan yang harus dihadapi.

7. Sistem evaluasi keterampilan menari berbasis IT dapat digunakan sebagai pendiagnostik kelayakan siswa sebelum mengikuti ujian kenaikan tingkat yang dilakukan sanggar tari.

\section{REFERENSI}

Boyatzis, Richard E., Competencies in the 21st Century. Journal of Management Development Vol. 27 No. 1, 2008 pp. 5-12.

Crooks, Terence J, The Impact of Classroom Evaluation Practices on Students. Journal: Review of Educational Research, Vol. 58, No. 4 (Winter, 1988), pp. 438-481.

Goodhue, D.L. Understanding User Evaluation of Information Sistem, Journal: Management Science, Desember, 1995, 1827 -1844.

Hattie, John and Helen Timperley, The Power of Feedback. Journal: Review of Educational Research March 2007, Vol. 77, No. 1, pp. 81-112.

Hill, Janette R. and Michael J. Hannafin, Teaching and Learning in Digital Environments: The Resurgence of Resource-Based Learning Author(s). Educational Technology Research and Development, Vol. 49, No. 3 (2001), pp. $37-52$.

Jumaili, Salman, 2005. Jurnal SNA VIII: Kepercayaan Terhadap Teknologi Sistem Informasi Baru Dalam Evaluasi Kinerja Individual.

Krasnow, Donna M.S., and Steven J. Chatfield, Development of the "Performance Competence Evaluation Measure" Assessing Qualitative Aspects of Dance

Performance. Journal of Dance Medicine \& Science: Volume 13, Number 4, 2009.

Lawless, Kimberly A. and James W. Pellegrino, Professional Development in Integrating Technology Into Teaching and Learning: Knowns, Unknowns, and Ways to Pursue Better Questions and Answers. Journal: American Educational Research Association is collaborating with JSTOR to digitize, preserve and extend access to Review of Educational Research December 2007, Vol. 77, No. 4, pp. 575-614.

Morris, Anne and Helena Brading, E- literacy and the grey digital divide: a review with 
Jurnal SEMAR Vol. 7 No. 2, 2018 hal. 1 - 14

ISSN: 2302-3937 | Copyright (C LPPM Universitas Sebelas Maret Homepage: https://jurnal.uns.ac.id/jurnal-semar

recommendations, Journal of information literacy; ISSN 1750-5968 Volume 1 Issue 3 December 2007.

Stansberry, Susan L. and Angel D. Kymes. Transformative Learning through "Teaching With Technology" Electronic Portfolios, Journal of Adolescent \& Adult Literacy, Vol. 50, No. 6, Electronic Portfolios (Mar., 2007), pp. 488496.

Sukardi. 2009. Evaluasi Pendidikan: Prinsip \& Operasionalnya. Jakarta: Bumi Aksara. Triana, Dinny Devi; Indah Juniasih, 2018. IT-Based Movement Evaluation System in Dance Studios. Atlantis Press: Proceding 1st International Conference on Arts and Design Education (ICADE 2018). Advances in Social Science, Education and Humanities Research, volume 255 